\title{
プラズマ処理したポリェチレンテレフタレート布へのアクリル酸の 気相グラフト重合における酸素の影響
}

\author{
朴 東旭*1 ・宇山良公*2 ・筏 義人*2
}

（受付 1991 年 8 月 8 日・蕃査終了 1991 年 11 月 5 日）

\begin{abstract}
要 旨 組成比の異なるアルゴンー酸素混合ガスでグロー放電処理したポリエチレンテレフタレート (PET) 布 に，アクリル酸を気相にてグラフト重合した。 グラフト量は供給ガス中の酸素沄度の增加ととも単調に減少した が、酸素100\%でもグラフト重合は進行した，グラフト重合によって消費された重合活性種量とグラフト量との間 には相関関倸がありこの両者から計算したグラフト銷の分子量は混合気体の組成に無関係に約 15000 であった。 一方、クロー放電処理したPET布に，モノマーガスー酸素湿合気体を導入させ，遊離ラシカル法によるグラフト重 合を行ったところ，モノマーガス中の酸素洤度の增加とともにグラフト量は急激に減少し，酸素溚度が50\%以上 ではほとんどゼロになった．グラフト重合前後の重合活性種量とグラフト量との関係から算出したグラフト銷の分 子量は，この場合あ酸素濃度によらずほぼ一定であった，表面グラフト重合を行ったPET布は，グラフト量が2 $\mu \mathrm{g} / \mathrm{cm}^{2}$ 以上では, 綿布に近い水濡れ性を示した。
\end{abstract}

\section{1 粕言}

高分子材料の表面改質法の一つとして表面グラフト化 が知られている. 高エネルギー放射線や光を利用したグ ラフト重合では, 前照射法以外に照射しながらグラフト 重合を行う同時重合法も可能である. しかし, 低温プラ ズマで同時照射すると、グラフト重合の開始の前にモ， マーのプラズ重合が起こってしまう可能性が高い。し たがって，ブラスママによるグラフト重合の場合には，前 報1).2)で述べたように, まず, プシズマ処理によって高分 子表面に重合活性種をつくり，そこからビニル系モ， マーを重合し、グラフト高分子鎖を表面に導入する.こ のようなプラズマグラフト重合は，(1) プラズマ処理に よって高分子表面に生成した遊離ラジカルを直接的に重 合開始に利用する遊離ラジカル法と, (2) プラズマ処理 によって高分子表面にペルオキシドをつくっておき，そ れをモノマーの存在下で開裂させ, 生成したオキシラシ カルを重合開始に利用するペルオキシド法の二つに分類 できる，放射線を利用したグラフト重合では，放射線が 高分子基質内部にまで遊離ラジカルを形成してしまうた め, 得られたグラフト化高分子材料のバルク特性も一般 に大きく変化する ${ }^{3) ~}$. 光やプラズマを利用したグラフ 卜重合においても,グラフト率を数\%以上にまで高め ることも可能であるがフ 10), 表面改質の場合には, その ような高いグラフト率は不必要である.

*1 中国康复研究中心（中国北京市 P. O. Box 2619）

*2 京都大学生体医療工学研究センター（『606 京都市左京区 聖嫨院川原町 53)
高分子材料のバルク特性を損ねることなく表面層のみ をグラフト化して表面を改質するためには，グラフト重 合活性種である遊離ラジカルあるいはペルオキシドの導 入を，高分子基質表面層に限定させることが必須条件と なる。しかし，実際には，活性種生成を極表面層に限定 させることは容易でなく，グラフト化層が基質表面層か ら数 $100 \mathrm{~nm}$ 数 $\mu \mathrm{m}$ に及ぶ場合がある゙"). そのため, グ ラフト重合を抑制することも必要である. われわれは, すでに被処理高分子材料としてポリエチレンテレフタ レート (PET) 布を選び, 上述の二つの方法により，その 表面を親水化する研究を行った ${ }^{1), 21}$. 本報では，遊離ラシ カル法による気相グラフト重合の結果を報告する. 特 に, 遊離ラジカル法においては, プラズマ照射時及びモ ノマーの重合時における残存酸素がグラフト重合に大き く影響されると思われるので, その酸素効果について検 討した。

\section{2 実験}

\section{1 試料及ひ試薬}

本実験に用いた試料はPET フィラメントからなる織 物であり, 帝人(株)製品テトロン・トロピカル (平織, 夕テとヨコ共に $150 \mathrm{D} / 48$ 本， 60 本/インチ）である. フィラメントの太さは約 3.0 デニール, 織維の表面積は $1530 \mathrm{~cm}^{2} / \mathrm{g}$ である. PET 布試料を $9 \mathrm{~cm} \times 5 \mathrm{~cm}$ の矩形に 切断し, メタノールで 24 時間ソックスレー抽出した後 に実験に供した。気相グラフト重合に用いたモノマー は, 北京東方化工公司製の重合グレードアクリル酸 (AA)である.アルゴン及び酸素ガスは純度 $99.999 \% の$ 


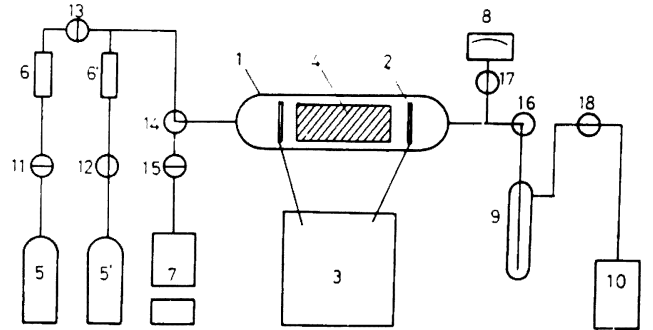

Fig. 1. Schematic representation of the apparatus used for the glow discharge treatment and vapor-phase graft polymerization. 1 , reactor; 2 , electrodes; $3, \mathrm{RF}$ supply; 4, sample; 5,5', argon and oxygen gas cylinders; 6,6', flow meters; 7, monomer evaporator; 8 , Pirani gauge; 9, trap; 10, vacuum pump; $11 \sim 18$, valves.

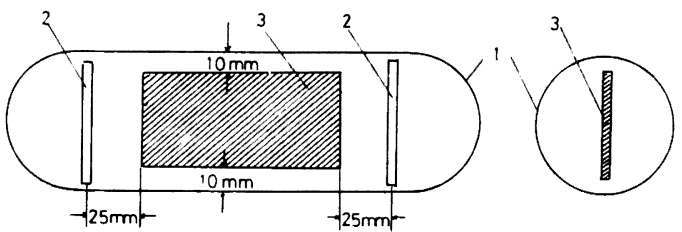

Fig. 2. Position of the PET sample in the reactor. 1, reactor; 2 , electrodes; 3 , PET sample.

市眅品である。 ラジカル重合活性種の定量に用いた 1,1. ジフェニル-2-ピクリルヒドラジル (DPPH) はシグマ社 製である.

\section{2 プラズマ処理及ひ気相グラフト重合}

用いたプラズマ反応装置の概略を Fig. 1 に示す。使用 周波数は $13.56 \mathrm{MHz}$ である. 反応シリンダーは, 第 2 報2)で用いたもの（内径 $7 \mathrm{~cm}$, 長さ $20 \mathrm{~cm}$ ） と同一であ り，その電極間距離を $14 \mathrm{~cm}$ に設定した後，PET 布試料 を、Fig. 2 に示すように，管内に固定した，反応器内の圧 力が $0.27 \mathrm{~Pa}$ になるまで咸压した後，アルゴンガスと酸 素ガスを単独または混合下で器内圧力が $5.6 \mathrm{~Pa}$ になる

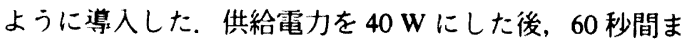
たは 120 秒間グロー放電した。 ガス導入を中止すると同 時に, 反応器内压力が再び $0.266 \mathrm{~Pa}$ になるまで減圧した 後、直ちにモノマーガスを $80 \mathrm{~Pa}$ の圧力下で 15 分間導 入した. AA モノマー蒸気と酸素ガスの混合比はそれら の流量で調節した。

\section{3 表面ラジカル重合活性種の測定}

グロー放電処理によって PET 材料表面に生成したう ジカル重合活性種を DPPH 法1). 12)によって定量した。フ ラズマ空間分布の影響2を考慮し，PET 布試料は，プラ ズマ処理後空気中に取り出し，Fig. 3 に示すように切り 取って測定に供した。正確に科取した試料をDPPHの ベンゼン游液に浸漬し， $70^{\circ} \mathrm{C} に て 8$ 時間加熱した。 その

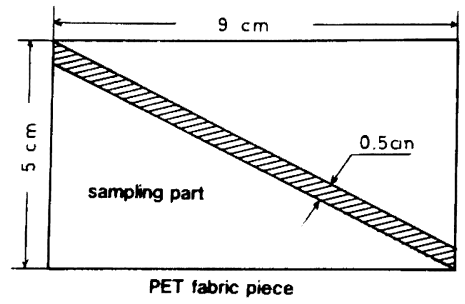

Fig. 3. Sampling of the PET fabric for measuring the free radicals by the DPPH method.

後、溶液の $520 \mathrm{~nm}$ における吸光度 (OD) を測定した。 末処理の PET 試料についても，同梯の DPPH 反応を 行って吸光度を測定し, 両者の吸光度の差から DPPH の減少量を求めた。重合活性種は酸素によってすへてぺ

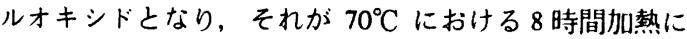
よってすべて分解すると同時に生成したラジカルに DPPH がすべて付加したと仮定して，そのDPPH の減 少量から重合活性種の表面濃度を算出した. DPPHのへ ンゼン溶液の調製には，チオフェン類を含まないベンゼ ンを用い，ODが 1.0 になるようにDPPH の濃度を選ん だ. $520 \mathrm{~nm}$ における DPPH のモル吸光係数は $1.18 \times 10^{4}$ $l \cdot \mathrm{mol}^{-1} \cdot \mathrm{cm}^{-1}$ である.

\section{4 グラフト重合量と表面濡れ測定}

表面グラフト重合量は，グラフト重合による PET の 重量增加から求めた，副生した木モ重合体は 20 時間の 熱水抽出によって行った。

表面濡孔性は, 恒温恒湿 $\left(25^{\circ} \mathrm{C}, 65 \%\right)$ 下で三日間保存 した PET 布の表面上 $2 \mathrm{~cm}$ の位置から， 約 $30 \mu l$ の水滴 を落下したとき, 水滴が布に完全に吸収されてその反射 光が消失するまでの時間, すなわち wicking time で評価 した.

\section{3 結果と考察}

\section{1 グロー放電処理ガス中の酸素の影䈏}

高分子表面に生成した遊離ラジカルを重合活性種に用 いる場合, 通常, 酸素の重合禁止効果を避けるために, 酸素を含まないアルゴンなどの非酸化性ガスでグロー放 電処理する。しかし，それらのガスから完全に酸素を除 去するのは, 特に大規模でグロー放電処理する場合, 容 易ではない，そこで，まず，我々は酸素の影響を調べる 目的で, 酸素濃度の異なるアルゴン一酸素混合ガスでグ ロー放電処理したPET 布に対して，グロー放電処理の 供給混合ガスの流量比のみを变化させて，AA モノマー の気相グラフト重合を行った，得られた結果を Fig. 4 に 示す。その結果から明らかなように, 酸素濃度の増加と ともに表面グラフト重合量は単調に減少している。しか し， 100\% の酸素ガスでグロー放電処理した場合でも， グラフト重合がかなり進行しているのがわかる．本帮験 


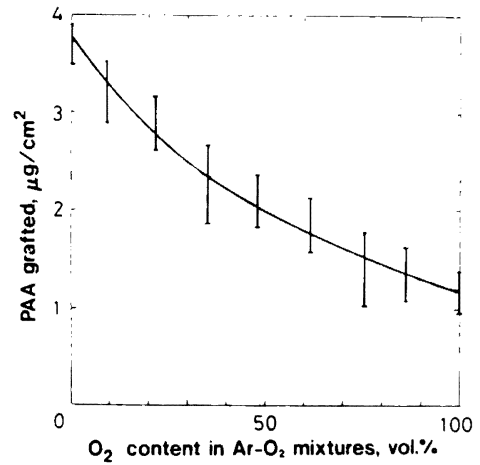

Fig. 4. Influence of $\mathrm{O}_{2}$ content in $\mathrm{Ar}-\mathrm{O}_{2}$ mixtures for plasma treatment on the surface concentration of PAA grafted onto PET.

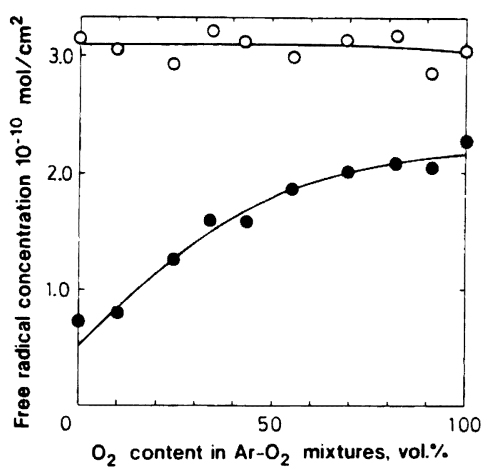

Fig. 5. Surface concentration of free radicals before and after polymerization as a function of $\mathrm{O}_{2}$ content in Ar- $\mathrm{O}_{2}$ mixtures. $\mathrm{O}$, before polymerization but after glow treatment; $\bigcirc$, after polymerization.

の条件ドでは，アルゴンプラズマばかりでなく，酸素プ ラズマによっても PET 表面に遊離ラジカルが生成し, それがグラフト反応の開始点になると思われる，一方， プラズマ化されていない分子状酸素は表面上のラジカル に結合して安定なペルオキシドをつくってグラフト開始 点を減少させると考えられる。したがって，グロ一放電 処理ガス昍酸素濃度が高いほど, 引き続いて起こるグ ラフト重合に及ばす影響も大きいであろう。この点をさ らに検討するために，気相グラフト重合の前後における PET 材料表面のラジカル量を測定した。 その結果を Fig. 5 に示す。明らかに，供給ガスが非酸化性ガス（アルゴ ン）または酸化性ガス（酸素）にかかわらず，同一気压 及び问一時間でグロー放電処理した場合, PET 表面に生 成したラジカル重合活性種濃度はほぼ一定である。しか し，このグロー放電処理 PET をただちに酸素の存在し ない条件トで父相重合させて得られたグラフト化 PET 表醏にもかなりのラジカル重合活性種が残存し, その量

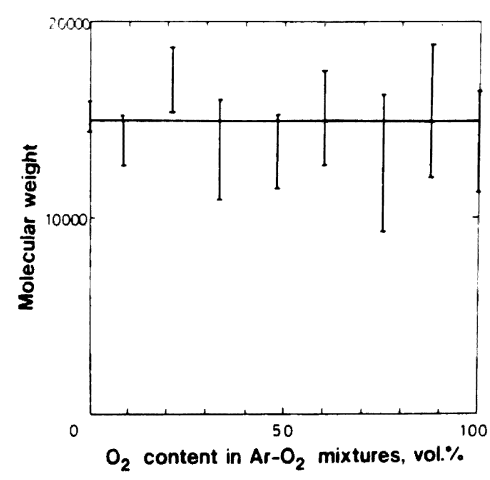

Fig. 6. Calculated molecular weights of graft chains based on the graft amounts and free radicals consumed during graft polymerization.

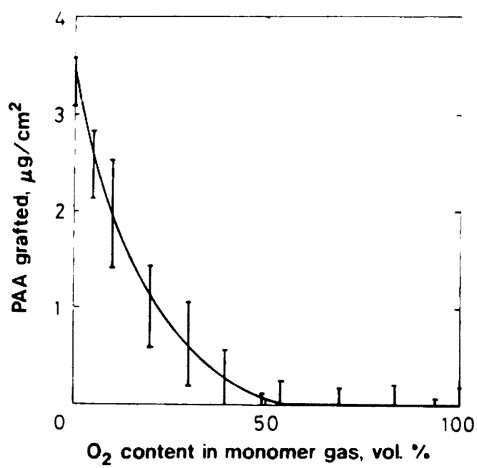

Fig. 7. Influence of $\mathrm{O}_{2}$ content in the monomer $-\mathrm{O}_{2}$ mixtures on the surface concentration of PAA grafted onto PET.

は, 供給ガス中の酸素濃度が高いはど多かった。本実験 では,グラフト重合温度が $40^{\circ} \mathrm{C}$ 以下と低いため, ペルオ キシドの熱分解によるオキシラジカルの生成はほとんど 起こらず, 遊離ラジカルのみがグラフト重合を開始した と思われる。

いま，グラフト重合量をグラフト重合によって消費さ れた重合活性種量（グラフト重合前後における重合活性 種量の差) で割ると，グラフト鎖の分子量を求めること ができる.ただし，このとき，ホモ重合体は完全に除去 されたと仮定する. そのようにして計算した結果を Fig. 6 に示した。図にみられるように, 分子量は約 15000 と 混合気体の組成に無関係にほぼ一定である。おそらく, このグラフト鎖の分子量はモ/マーへの成長ラジカルの 連鎖移動によって決定されると思われ, 重合時のモ， マー濃度が一定であるため, 分子量も一定になったと考 えられる.

\section{2 モノマーガス中の酸素の影䇾}

遊離ラジカル法によるプラズマグラフト重合反心にお 


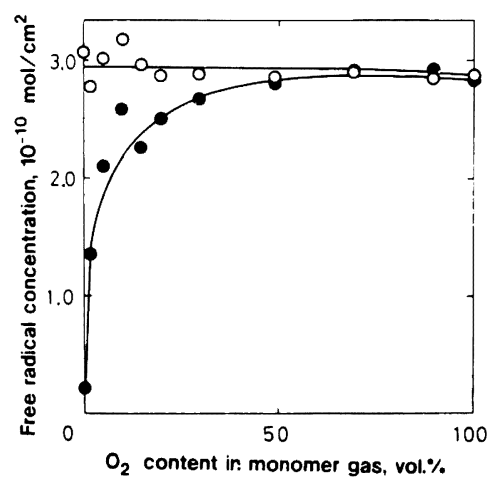

Fig. 8. Surface concentration of free radicals before and after polymerization as a function of $\mathrm{O}_{2}$ content in monomer $-\mathrm{O}_{2}$ mixtures. $\mathrm{O}$, before polymerization but after plasma treatment; $\boldsymbol{O}$, after polymerization.

Table 1. Calculated molecular weights of graft chains based on the graft amount and surface concentration of free radicals

\begin{tabular}{cccc}
\hline \hline \multirow{2}{*}{$\begin{array}{c}\mathrm{O}_{2} \text { content in } \\
\text { monomer gas } \\
(\text { vol.\%) }\end{array}$} & \multicolumn{3}{c}{ Molecular weight } \\
\cline { 2 - 4 } & Maximum & Minimurn & Average \\
\hline 0 & 12900 & 11000 & 12100 \\
5 & 13300 & 10000 & 11900 \\
10 & 31200 & 17500 & 23700 \\
30 & 30000 & 6000 & 12500 \\
50 & 12000 & 4000 & 8000 \\
\hline
\end{tabular}

いて，モノマーガス中の酸素が重合反応に影響を与える ことは，ラジカル機構で進行するためと予想される。 そ の定量的研究はほとんど行われていない，そこで，我々 は，アルゴンガスでグロー放電処理した PET 試料に対 して, 既知量の酸素を含む AA モノマーガスの気相グラ フト重合を行った. Fig. 7 に PET 表面へのグラフト重合 に及ぼすモノマーガス中の酸素濃度の影響を示す。この 実験では，100\%アルゴンガスで 60 秒間グロー放電処理 したPETに対して気相グラフト重合した. グラフト重 合量は, 図にみられるように, モノマーガス中の酸素濃 度が增加するにつれて急激に減少し，50\%以上ではほと んど測定できないほど低かった。

Fig. 8 に, 酸素濃度の異なるモ/マーガスでグラフト 重合したPET 布の重合活性種のグラフト重合前後にお ける濃度を示した。この気相グラフト重合に供したPET のグロー放電処理は $100 \%$ のアルゴンガスで 60 秒間 行った，当然ながら，グラフト重合前における重合活性 種濃度はグラフト重合とは無関係であり, 約 $3.0 \times 10^{-10}$ $\mathrm{mol} / \mathrm{cm}^{2}$ とほぼ一定であった。 一方, グラフト重合後の 重合活性種濃度はモノマーガス中の酸素濃度の增加に

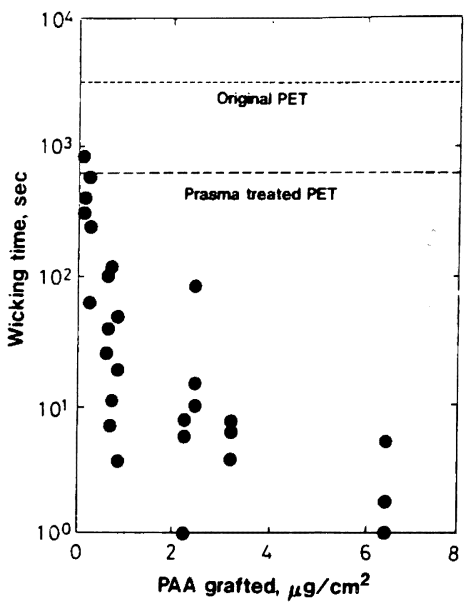

Fig. 9. Dependence of the wettability of the surfacemodified PET fabric on the surface concentration of PAA grafted.

伴って急激な上昇を示し, 酸素濃度が $50 \%$ 以上では重 合前に近い値を示した。これは，よく知られているよう に，ガス中の酸素が成長中のグラフトポリマーラジカル と結合してその成長を停止したためであろう。グラフト 重合前後における重合活性種の濃度差とグラフト重合量 から算出したグラフト重合鎖の分子量を Table 1 に示し たが,この場合も，分子量は酸素濃度に無関係にほぼ一 定であることがわかる. 分子量は Fig. 6 の値より，少し 低いようである.

\section{3 グラフト処理効果}

PET 布の表面グラフト改質効果を水濡れ性により評 価した. Fig. 9 に, PET 布の水濡れ性とグラフト量との 関係を示す。グラフト重合量が $2 \mu \mathrm{g} / \mathrm{cm}^{2}$ 以上の PET 布 は綿布に近い表面濡れ性をむっている。綿布の wicking time は 1 秒以下でほぼ瞬間的な時間である. 良好なグラ フト重合改質効果を獲得するためには，グロ一放電処理 時ならびにグラフト重合時における酸素の混入をできる 限り避けることが望ましいことがわかる。

$$
4 \text { 結語 }
$$

高分子表面のラジカル重合活性種濃度を測定すること により，遊離ラジカル法によるプラズマ気相グラフト重 合に及ぼす酸素の影響を定量的に考察することができ た.

グロー放電処理ガス中の酸素ならびにモノマーガス中 の酸素は，いずれも，PET 表面へのグラフト重合反応を 大きく抑制した．しかし，その抑制作用は，後者の方が 前者よりあはるかに大きかった。

なお、ここではふれなかったが、ペルオキシド法によ る研究結果については第 4 報で報告することにする. 
勆 辞 本研究の一部の実験に協力していただいた北京大学 織維研究所の劉静 $\mathrm{C}$ 程師, 北京師範大学の卒研生篩君柏君に感 射します。

\section{文献}

1) 朴 東旭，宇山良公，筏 義人，高分子論文集，48，529 (1991).

2) 朴 東旭, 宇山良公, 筏 義人, 高分子論文集, 48, 535 (1991).

3) A. Chapiro, J. Eur. Polym., 19, 859 (1983).

4) V. A. Postnikov, N. J. Lukin, B. V. Maslov, and N. A. Plate, Polym. Bull., 3, 75 (1980).

5) J. P. Lawler and A. Charlesby, Radiat. Phys. Chem., 15, 595
(1980).

6) B. Jansen, Polym. Sci. Technol., 23, 287 (1983).

7) Y. Ogiwara, M. Takumi, and H. Kubota, J. Appl. Polym. Sci., 27, 3743 (1982).

8) Y. L. Hsieh, C. Pugh, and M. S. Ellison, J. Appl. Polym. Sci., 29, 3549 (1984).

9) Y. L. Hsieh, Y. Chen, and Y. Elizabeth, Ind. Eng. Chem. Prod. Res. Dev., 24(2), 246 (1985).

10) Y. L. Hsieh and D. Timm, Polym. Mater. Sci. Eng., 56, 323 (1987).

11) E. Uchida, Y. Uyama, H. Iwata, and Y. Ikada, J. Polym. Sci., A, Polym. Chem., 28, 2837 (1990).

12) M. Suzuki, A. Kishida, H. Iwata, and Y. Ikada, Macromolecules, 19, 1804 (1986).

Influence of Oxygen on the Vapor-Phase Graft Polymerization with Acrylic Acid onto the Plasma-Treated Polyester Fabrics

D.-X. PIAO*1, Yoshikimi UYAMA ${ }^{* 2}$, and Yoshito IKADA*2

*1 China Rehabilitation Research Centre, Beijing, China

${ }^{* 2}$ Research Center for Biomedical Engineering, Kyoto University ( 53 Kawahara-cho, Shogoin, Sakyo-ku, Kyoto, 606 Japan)

A poly(ethylene terephthalate) (PET) fabric was plasma-treated with gas mixtures having various contents of oxygen in argon, and subsequently surface-grafted with acrylic acid in vapor phase. Although the graft amount decreased monotonously with the increasing oxygen content in the plasma gas, the graft polymerization proceeded even when the PET fabric was plasma-treated in pure oxygen. The amount of acrylic acid surface-grafted on the PET fabrics was closely related with the amount of active species consumed during the graft polymerization. The calculated molecular weights of graft chains were almost constant at 15000 , irrespective of the oxygen concentration. On the other hand, if the graft polymerization was carried out with the free radical method using monomer-oxygen mixtures, the graft amount decreased drastically with the increasing oxygen concentration, virtually to zero when the concentration became higher than $50 \%$. In this case also, the molecular weights of graft chains calculated from the graft amount and the differential surface concentration of free radicals before and after graft polymerization maintained a constant value, regardless of the oxygen concentration within the range of 0 to $50 \%$ of oxygen. The PET fabrics surface-grafted with acrylic acid became hydrophilic as highly as natural cotton.

KEY WORDS Effects of Oxygen / Plasma Treatment / Polyester Fabrics / Vapor-Phase Graft Polymerization / Acrylic Acid /

(Received August 8, 1991: Accepted November 5, 1991)

[Kobunshi Ronbunshu, 49(5), 401-405 (1992)] 